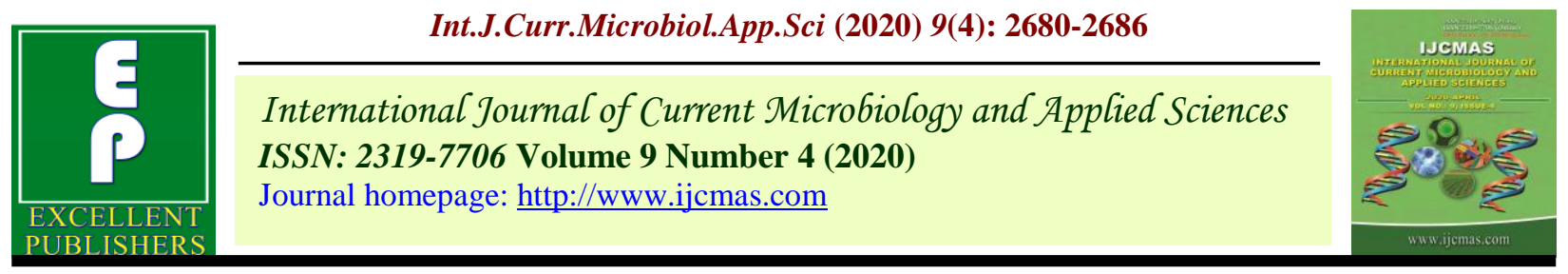

Original Research Article

https://doi.org/10.20546/ijcmas.2020.904.319

\title{
Uptake and Available Nutrient Status of Maize (Zea mays L.) as Influenced by Plant Growth Promoting Rhizobacteria
}

\author{
K. Harish, P. A. Gowda, L. Krishna Naik and S. Umesha* \\ Department of Agricultural Microbiology, College of Agriculture, \\ UAS, GKVK, Bengaluru- 65, India
}

\begin{tabular}{|c|}
\hline Keywords \\
\hline $\begin{array}{l}\text { Maize, PGPR, } \\
\text { Azotobacter, } \\
\text { Aspergillus, } \\
\text { Pseudomonas, } \\
\text { Glomus }\end{array}$ \\
\hline Article Info \\
\hline $\begin{array}{l}\text { Accepted: } \\
22 \text { March } 2020 \\
\text { Available Online: } \\
10 \text { April } 2020\end{array}$ \\
\hline
\end{tabular}

\section{A B S T R A C T}

To know the efficiency of plant growth promoting rhizobacteria with different levels of inorganic fertilizers on uptake and available nutrient status of maize, a field experiment was conducted during 2010 using the maize cultivar Nithyashree (NAH 2049). Experiment was laid out in randomized complete block design with fourteen treatments and three replications. The treatment having $75 \% \mathrm{NP}+100 \% \mathrm{~K}+$ A. chroococcum + A. awamori + G. fasciculatum $(184.50 \mathrm{~kg} / \mathrm{ha}$ of $\mathrm{N}), 75 \% \mathrm{NP}+100 \% \mathrm{~K}+$ A. chroococcum $+A$. awamori $+P$. fluorescens $(38.48 \mathrm{~kg} / \mathrm{ha}$ of $\mathrm{P})$ and $100 \% \mathrm{NPK}+$ A. chroococcum + A. awamori + G. fasciculatum (181.13 $\mathrm{kg} / \mathrm{ha} \mathrm{K}$ ) were showed highest uptake of NPK as compare to treatment receiving $75 \% \mathrm{RDF}$. Whereas in case of available nutrient status of the soil has noticed highest in the $75 \% \mathrm{NP}+100 \% \mathrm{~K}+A$. chroococcum + A. awamori + P. fluorescens (288.37 and $192.90 \mathrm{~kg}$ of $\mathrm{N}$ and $\mathrm{K}$ ), and $100 \%$ $\mathrm{NPK}+A$. chroococcum $+A$. awamori $+P$. fluorescens $(30.77 \mathrm{Kg}$ of $\mathrm{P}$ ) as compared to rest of the treatments.

\section{Introduction}

Maize (Zea mays L.), belongs to the family Poaceae (Gramineae) and it is considered as king of crops and queen of cereals. Globally maize is the second most important cereal grain after wheat. The world area under maize crop is about 139.68 million hectares with the production of 599.97 million metric tonnes. In India, maize is grown in an area of $8.12 \mathrm{mha}$ with an annual production of about $19.77 \mathrm{mt}$.
The average productivity of maize in India is about $2400 \mathrm{~kg} \mathrm{ha}^{-1}$ (Anonymous, 2009). In Karnataka maize is grown in an area of 0.960 mha producing $2.64 \mathrm{mt}$ with a productivity of $3012 \mathrm{~kg} \mathrm{ha}^{-1}$ (Anonymous, 2009). This crop is having special characteristics that include its carbon pathway (C4), wider adaptability, higher multiplication ratio, desirable architecture, superior transpiration efficiency, high versatile use of fertilizes etc. (Karthikeyan et al., 2006) 
PGPR are important in managing plant growth because of their effects on soil condition, nutrient availability, disease suppression, growth and yields (Mohammad Yazdani et al., 2009). PGPR microorganisms have been emerged as a supplement to mineral fertilizer and hold a promise to improve the yield of crops. The PGPR microorganisms are found to have positive contribution to soil fertility, resulting in an increase in crop yield without causing any type of environmental, water or soil hazards. PGPR microorganisms also contributing to nitrogen fixation besides producing growth hormones such as auxins, gibberellins, Cytokinins (Yadav et al., 1992).

\section{Materials and Methods}

The study was conducted at Agricultural Research Station, Bhavikere Farm, Bhavikere, University of Agricultural Sciences, Bangalore during Kharif 2010. The laboratory studies were conducted in the Department of Agricultural Microbiology, UAS, GKVK, Bangalore.

The experimental site is situated between 130 42' North latitude and 750 51' East longitude and an altitude of 695 meters above mean sea level. It lies in the Southern Transitional Zone (Zone VII) of Karnataka. The soil of the experimental site was red sandy loam. The soil was neutral in reaction, medium in available nitrogen, phosphorus and potassium. The experiment was laid out in randomized complete block design (RCBD) with 12 treatment combinations and 3 replications. The cultures of PGPR microorganisms obtained from the Department of Agriculture Microbiology, UAS, GKVK, Bangalore.

\section{Collection and preparation of plant samples}

The collected grain and plant samples at the time of harvest were dried at $60^{\circ} \mathrm{C}$ in a hot air oven, powdered using a grinder fitted with stainless steel blades and preserved in polythene bags for further analysis (Jackson, 1973).

\section{Nitrogen}

Total nitrogen in plant samples was determined by Kjeldahl's method of nitrogen determination as described by Jackson (1973). In this method, a powdered sample of $0.5 \mathrm{~g}$ was digested with conc. $\mathrm{H}_{2} \mathrm{SO}_{4}$ in presence of digestion mixture $\left(\mathrm{K}_{2} \mathrm{SO}_{4}: \mathrm{CuSO}_{4} .5 \mathrm{H}_{2} \mathrm{O}: \mathrm{Se}\right.$ in the proportion of 100:20:1) and distilled under alkaline medium. The liberated NH3 was trapped in boric acid containing mixed indicator and titrated against standard $\mathrm{H}_{2} \mathrm{SO}_{4}$.

\section{Digestion of plant samples with di-acid mixture}

A powdered sample of $0.5 \mathrm{~g}$ was predigested with $5 \mathrm{ml}$ of concentrated $\mathrm{HNO} 3$ and again digested with a di-acid mixture (HNO3: $\mathrm{HClO} 4$ in the proportion of 10:4 ratio). Volume of the digest was made up to $100 \mathrm{ml}$ with distilled water and preserved for $\mathrm{N}, \mathrm{P}$ and K analysis (Jackson, 1973).

\section{Phosphorus}

The total phosphorus content in grain and stover of maize were determined by taking a known volume of the digested samples by adopting the Vanadomolybdophosphoric yellow colour method as described by Jackson (1973).

\section{Potassium}

Using the respective di-acid digests of grain and stover, the total potassium content of the above materials was estimated by atomizing the diluted digest to a calibrated flame photometer under suitable measuring conditions as described by Jackson (1973). 
Uptake of nutrients by stover and grains of maize

The uptake of nutrients by different parts of maize plants was worked out by multiplying the nutrient content and dry matter yield of the plant part as given in the following formula.

Nutrient uptake $(\mathrm{Kg}$ ha-1) $=$

Nutrient concentration $\times$ Weight of dry matter $(\%)$

(Kg ha-1)

determined by flame photometry as described by Jackson (1973).

\section{Results and Discussion}

Higher uptake of nitrogen $(184.50 \mathrm{~kg} / \mathrm{ha})$ was obtained in the treatment of application of 75 per cent of $\mathrm{N}$ and $\mathrm{P}+100$ per cent $\mathrm{K}+$ A.chroococcum + A. awamori + Glomus fasciculatum $\left(\mathrm{T}_{9}\right)$. This might be due to the nitrogen fixing bacteria and subsequent release of $\mathrm{N}$ by mineralization of bacterial cells and also increased $\mathrm{N}$ availability due to the inorganic $\mathrm{N}$ fertilizer application. A similar result of increased $\mathrm{N}$-uptake by plants in N-fixing organism inoculated plants was obtained by Sanni (1976).

\section{Collection of soil samples}

During the field experiment, a composite soil sample was collected from each plot before sowing and also after harvest of the maize crop. The collected soil samples were dried under shade, powdered using wooden pestle and mortar and passed through $2 \mathrm{~mm}$ sieve and preserved for analysis.

\section{Available nitrogen}

Available nitrogen in soils was determined by alkaline potassium permanganate method as described by Subbaiah and Asija (1956)

\section{Available phosphorus}

Available phosphorus was extracted from soil using Olsen's extractant and the concentration of phosphorus present in the extract was determined by chlorostannous reduced molybdophosphoric blue colour method in HCl system (Jackson, 1973).

\section{Available potassium}

Available potassium was extracted from soil using neutral $\mathrm{N}$ ammonium acetate at 1:5 soil: extract ratio and the concentration of potassium present in the extract was

The highest amount of P (38.48 kg/ha) uptake was obtained in the treatment of $75 \% \mathrm{NP}+$ $100 \% \mathrm{~K}+$ A.chroococcum + A.awamori + P.fluorescens $\left(\mathrm{T}_{8}\right)$. This might be due to the application of $\mathrm{P}$ solubilizers and $\mathrm{P}$ mobilizers which enhance both solubilization and translocation of $\mathrm{P}$ into the plant. The results of the present study are in accordance with the results obtained by Sanni (1976) and Muromtsev et al., (1990).

The higher uptake of $\mathrm{K}(181.13 \mathrm{~kg} / \mathrm{ha})$ was obtained in the treatment of $100 \%$ NPK + A.chroococcum + A.awamori + G.fasciculatum $\left(\mathrm{T}_{12}\right)$ this might be due to the inoculation of VAM and other microbial groups which help in mobilization of $\mathrm{K}$ in plant (Sanni, 1976 and Muromtsev et al., 1990).

Higher amount of available nitrogen (288.37 $\mathrm{kg} / \mathrm{ha}$ ) was obtained in the treatment of $75 \%$ $\mathrm{NP}+100 \% \mathrm{~K}+$ A.chroococcum + A.awamori + P.fluorescens $\left(\mathrm{T}_{8}\right)$ this might be due to more number of the nitrogen fixing bacterial dead cells and subsequent mineralization contribute towards the nitrogen availability of plants, similar results have been obtained by Goswami (1976) (Table 1 and 2). 
Table.1 Effect of inoculation of PGPR microorganisms with different levels of inorganic fertilizer on uptake of NPK (kg/ha) in maize rhizosphere after harvest

\begin{tabular}{|c|c|c|c|}
\hline Treatments & $\mathbf{N}$ & $\mathbf{P}$ & $\mathbf{K}$ \\
\hline $\mathrm{T}_{1}-100 \% \mathrm{RDF}$ & 162.77 & 20.83 & 159.53 \\
\hline $\mathrm{T}_{2}-75 \% \mathrm{RDF}$ & 159.63 & 19.40 & 154.47 \\
\hline $\mathrm{T}_{3}$-Recommended NPK+ Azotobacter chroococcum & 182.00 & 30.63 & $171.60 \mathrm{~A}$ \\
\hline $\mathbf{T}_{4}$-Recommended NPK+ Aspergillus awamori & 166.27 & 25.60 & 163.47 \\
\hline $\mathrm{T}_{5}$ - Recommended NPK + Pseudomonas fluorescens & 169.33 & 28.00 & 166.90 \\
\hline T $_{6}$ - Recommended NPK+ Glomus fasciculatum & 167.30 & 25.03 & 165.40 \\
\hline $\mathrm{T}_{7}-75 \% \mathrm{NP}+100 \% \mathrm{~K}+$ A.chroococcum + A.awamori & 172.03 & 27.57 & 168.03 \\
\hline $\mathrm{T}_{8}-75 \% \mathrm{NP}+100 \% \mathrm{~K}+$ A.chroococcum + A.awamori + P.fluorescens & 175.83 & 38.48 & 169.50 \\
\hline $\mathrm{T}_{9}-75 \% \mathrm{NP}+100 \% \mathrm{~K}+$ A.chroococcum + A.awamori + G.fasciculatum & 184.50 & 36.50 & 175.77 \\
\hline $\mathrm{T}_{10}-100 \% \mathrm{NPK}+$ A.chroococcum + A.awamori & 173.53 & 30.27 & 170.23 \\
\hline $\mathrm{T}_{11}-100 \% \mathrm{NPK}+$ A.chroococcum + A.awamori + P.fluorescens & 183.27 & 32.60 & 178.83 \\
\hline $\mathrm{T}_{12}-100 \% \mathrm{NPK}+$ A.chroococcum + A.awamori + G.fasciculatum & 176.77 & 37.03 & 181.13 \\
\hline $\mathrm{SEm} \pm$ & 1.26 & 0.74 & 2.62 \\
\hline C.D at $5 \%$ & 3.75 & 2.21 & 7.77 \\
\hline
\end{tabular}


Table.2 Effect of inoculation of PGPR microorganisms with different levels of inorganic fertilizer on available NPK (kg/ha) in maize rhizosphere after harvest

\begin{tabular}{|c|c|c|c|}
\hline \multirow[b]{2}{*}{ Treatments } & \multicolumn{3}{|c|}{ Available NPK kg/ha } \\
\hline & Available $\mathbf{N}$ & Available P & Available K \\
\hline $\mathrm{T}_{1}-100 \% \mathrm{RDF}$ & 256.43 & 16.70 & 172.97 \\
\hline $\mathrm{T}_{2}-75 \% \mathrm{RDF}$ & 251.57 & 15.93 & 170.77 \\
\hline $\mathrm{T}_{3}$-Recommended NPK+ Azotobacter chroococcum & 284.90 & 27.60 & 186.57 \\
\hline $\mathrm{T}_{4}$-Recommended NPK + Aspergillus awamori & 271.30 & 26.23 & 182.10 \\
\hline $\mathrm{T}_{5}-$ Recommended NPK + Pseudomonas fluorescens & 274.93 & 28.47 & 183.40 \\
\hline $\mathrm{T}_{6}-$ Recommended NPK+ Glomus fasciculatum & 272.80 & 24.90 & 180.70 \\
\hline $\mathrm{T}_{7}-75 \% \mathrm{NP}+100 \% \mathrm{~K}+$ A.chroococcum + A.awamori & 275.80 & 23.83 & 185.27 \\
\hline $\mathrm{T}_{8}-75 \% \mathrm{NP}+100 \% \mathrm{~K}+$ A.chroococcum + A.awamori + P.fluorescens & 288.37 & 29.30 & 192.90 \\
\hline $\mathrm{T}_{9}-75 \% \mathrm{NP}+100 \% \mathrm{~K}+$ A.chroococcum + A.awamori + G.fasciculatum & 282.13 & 21.87 & 192.50 \\
\hline $\mathrm{T}_{10}-100 \% \mathrm{NPK}+$ A.chroococcum + A.awamori & 277.87 & 22.17 & 189.53 \\
\hline $\mathrm{T}_{11}-100 \% \mathrm{NPK}+$ A.chroococcum + A.awamori + P.fluorescens & 286.03 & 30.77 & 190.73 \\
\hline $\mathrm{T}_{12}-100 \% \mathrm{NPK}+$ A.chroococcum + A.awamori + G.fasciculatum & 283.63 & 25.47 & 187.57 \\
\hline $\mathrm{SEm} \pm$ & 1.72 & 0.83 & 2.04 \\
\hline C.D at $5 \%$ & 5.12 & 2.45 & 6.07 \\
\hline
\end{tabular}


Higher amount of available P $(30.77 \mathrm{~kg} / \mathrm{ha})$ was noticed in the treatment of $100 \%$ NPK + A.chroococcum + A.awamori + P.fluorescens $\left(\mathrm{T}_{11}\right)$ this might be due to the application phosphate solubilizers their organisms have greater efficiency in phosphate solubilization by production of various organic acid which convert unavailable $\mathrm{P}$ into available form. The result of present of investigation are in accordance with the result obtaining by Kang et al., (2007), where as Pseudomonas fluorescens produce oxalic and citric acids which are involved in the phosphate solubilization and convert them in to available form (Sridar et al.,1998) . Azotobacter is also involved in the phosphate solubilization by producing low molecular mass organic acids which convert unavailable $\mathrm{P}$ into available form as reported by Ivanova et al., (2006).

The higher amount of potash was obtained $(192.90 \mathrm{~kg} / \mathrm{ha})$ in the treatment of $75 \% \mathrm{NP}+$ $100 \% \mathrm{~K}+$ A.chroococcum + A.awamori + P.fluorescens $\left(\mathrm{T}_{8}\right)$ this might be due to the application of consortia of different PGPR organisms and their synergetic effect by producing different substances they increased available $\mathrm{K}$ to plants this was reported by Ahmed et al., (1996) and Amara and Dahdoh (1997) and Crozier et al., (1988).

\section{References}

Ahmed, A.T., K.W. Khalil, B.F.A. El-Ghany and Awadalla, S.Y. 1996, Ameliorating the properties of virgin sandy soil and its impact on wheat production. Desert Institute Bulletin, Egypt, publ., 46(2): 319- 339.

Amara, M.A.T. and M.S.A. Dahdoh, 1997. Effect of inoculation with plant growth promoting rhizobacteria (PGPR) on yield and up take of nutrients by wheat grown. Egyp. Soil sci., 37(4): 467-484.

Anonymous, 2009, Economics Survey 200809, Government of India, Ministry of
Finance Economic Division, pp. 191196.

Crozier, A., Arruda, P., Jasmin, J. M., Monterio, A. M. and Sandberg, G., 1988, Analysis of indole -3- acetic acid and related indoles in culture medium from Azospirillum liperum and Azospirillum brasilense. Appl. Environ. Microbiol., 54: 2833-2837.

Goswami, K.P., 1976, Worth of Azotobacter as a bacterial fertilizer. Fert. News., 21: 32-34

Ivanova. R, Bojinova. D, Nedialkova. K, 2006, Rock phosphate solubilization by soil bacteria, J. of Uni. of Che. Tec. and Met., 41: 297-302

Jackson, M.L., 1973, Soil Chemical Analysis, Prentice Hall of India (P.) Ltd., New Delhi.

Kang. S. C, Piyush Pandey, Rajat Khillon and Maheshwari. D. K., 2007, Process of rock phosphate solubilization by Aspergillus sp PS 104 in soil amended medium, J. Environ. Biol. 29(5), 743746

Karthikeyan A.S., Varadarajan D.K., Mukatira U.T., D'urzo M.P., Damsz B. and Raghothama K.G., 2006, Regulated expression of Arabidopsis phosphate transporters. Plant Physiology 130, 221233.

Mohammad Yazdani. M, Bahmanyar. M. A, Pirdashti. H and Esmaili, M. A., 2009, Effect of phosphate solubilizing microorganism and plant growth promoting rhizobacteria on yield and yield components of corn. World Ac. Sc, Eng and Tec 49: 209

Muromtsev., LI, C. Y. and Hung, L. L., 1990, Nitrogen-fixing (acetylenereducing) bacteria associated with ectomycorrhizae of Douglas-fir. Plant and Soil, 98: 425-428.

Sanni, S. O., 1976, Vesicular arbuscular mycorrhiza in some Nigerian soils and their effect on the growth of tomato, 
cowpea and maize, New Phytol., 77: 667-671

Sridar, R. and Santhanakrishnan, P., 1998, Studies on the compatibility of Trichoderma viridae and Pseudomonas fluorescens in cotton rhizosphere and their effect on plant growth. J. Soil Biol. Ecol., 18(1\&2): 94-97.

Subbaiah, B.V. and Asija, G.L., 1956, Rapid procedure for the estimation of available nitrogen in soils. Current Sci., 25: 259-260.

Yadav, A. K., Tandon, V. and Rao, H. S. P. (1992). In vitro anthelmintic efficacy of fresh tuber extract of Flemingia vestita against Ascaris suum. Fitoterapia. 63: 395-398.

\section{How to cite this article:}

Harish, K., P. A. Gowda, L. Krishna Naik and Umesha, S. 2020. Uptake and Available Nutrient Status of Maize (Zea mays L.) as Influenced by Plant Growth Promoting Rhizobacteria. Int.J.Curr.Microbiol.App.Sci. 9(04): 2680-2686. doi: https://doi.org/10.20546/ijcmas.2020.904.319 